\title{
6 Shooting the subversive: when non-normative linguistic practices go mainstream in the media
}

\author{
Tommaso M. Milani, Rickard fonsson and \\ Innocentia F. Mhlambi
}

\section{Introduction}

At first glance, Sweden and South Africa might seem to share very few traits. We could go as far as to suggest that they are opposite poles in a geographical, historical and sociopolitical sense, with Sweden as an 'old' democratic welfare state in the very north of the world at one end of the continuum, and South Africa at the other as a 'young' democracy of the South in which urban opulence exists next to extreme poverty. Despite these differences, the main argument of this chapter is that Sweden and South Africa do have something in common: in both contexts, particular forms of non-normative linguistic practices traditionally associated with youth have been 'strategically recontextualized' (Gal and Woolard 2001) in mainstream advertising for consumerist purposes. In order to illustrate this, we will bring into the spotlight three TV commercials that employ Tsotsitaal, on the one hand, and rinkebysvenska ('Rinkeby Swedish') and Swedish interlanguage, on the other. ${ }^{1}$ In no way do we mean to imply that these advertisements are representative of the entire marketing landscape in the two countries in question. We have chosen them because they are very popular, repeatedly broadcast through a variety of channels in Sweden and South Africa. The main point we make on the basis of this data set is that these advertisements provide us with 'local' vantage points

1 The Swedish advertisements analysed in this chapter are part of a larger corpus of data collected by Rickard Jonsson and Tommaso M. Milani over the last 10 years with a view to studying and understanding the social life of rinkebysvenska. The data set comprises media outputs (commercials, newspaper articles, TV-interviews and public panel debates), ethnographic observations in schools, interviews with teachers, principals and pupils (see also Jonsson 2007; Milani 2010; Milani and Jonsson 2012). The South African aspect of this paper is motivated by the comparative rationale underpinning this volume as well as an outspoken political commitment shared by the three authors of this chapter to employ a theoretical and empirical lens from the 'South' as heuristic tools through which to make sense and re-theorize the 'North'. This is in our view but one step in redressing the current epistemological imperialism of the north in sociolinguistic and discourse studies (see also Makoni and Mashiri 2007 for a similar point). 
from which to tap into larger 'global' sensitivities about ethnic and racial identities in late modernity.

Theoretically, we have been moved by recent developments towards what the anthropologists Comaroff and Comaroff (2012) have called a 'Theory from the South'. Their radical suggestion entails 'subvert[ing] the epistemological scaffolding' which posits the north as 'the wellspring of universal learning' and the South as 'a place of parochial wisdom, of antiquarian traditions, of exotic ways and means, and above all, of unprocessed data' (Comaroff and Comaroff 2012: 1). In their view, we should instead look at the Global South as a site that 'affords privileged insight into the workings of the world at large'. Reasoning along similar lines, we believe that postcoloniality provides us with a useful lens through which to read very disparate late-modern conditions of de-colonization and post-apartheid as well as enhanced transnational movements, diasporas, dislocations and conditions that 'ultimately [transcend] the very dualism of north and south' (Comaroff and Comaroff 2012: 47). Influenced by the work of Said (1978) and Loomba (1995), we understand postcoloniality not so much as something 'coming literally after colonialism and signifying its demise' (Loomba 1995: 245), but rather as a critical stance that seeks to tease out and understand the workings of discourses in reproducing or unsettling the dyadic opposition between a 'normal', 'familiar' or even 'superior' Self, and the 'deviant', 'strange' and 'inferior' ethnic and racial 'Other' (see Loomba 1995: 245 and Said 1978: 43).

In what follows, we will begin with a brief historical contextualization of Tsotsitaal and rinkebysvenska, followed by an analysis of relevant TV commercials. In the concluding section, we will discuss the differences and similarities between the advertisements in the light of a postcolonial approach to discourse data.

\section{Tsotsitaal and rinkebysvenska: two contexts, two histories}

Over the last thirty years or so, Tsotsitaal has increasingly been brought under the spotlight of (socio)linguistic analysis (Hurst 2009; Makhudu 1980, 2002; Mesthrie 2008; Ntshangase 1993, 2002). Historically, this linguistic phenomenon stems from the multilingual encounters that characterize early industrialization and urbanization among people from different racial and linguistic backgrounds in the mining areas of the Witwatersrand (Johannesburg) at the turn of the 20th century. Following Mesthrie (2008: 96), we employ the label Tsotsitaal as a hypernym for a variety of linguistic phenomena that go under very different names: flaaitaal, iscamtho, iskasi, ukuringa or itaal (see also Mesthrie 2008: 96). 
A detailed overview over this terminological morass lies outside the scope of this chapter (see, however, Mesthrie 2008). Suffice it to say, however, that the names indicate the various base languages upon which these linguistic phenomena are built: Afrikaans, isiZulu, seSotho, isiXhosa or tshiVenda. Etymologically, taal is the Afrikaans word for 'language', whereas tsotsi ('thug') seems to have originated from the English 'Zoot Suit', a particular cut of narrow-bottomed trousers popularized in South Africa through North American gangster films in the 1950s (Hurst 2009: 245).

That masculinity and criminality have become the prevalent cultural associations with Tsotsitaal is not particularly surprising, since this linguistic phenomenon developed for the most part among the urban male youth of the Freehold Areas (Sophiatown, Martindale and Alexandra) in the 1950s. This was a time when the African middle class and the general Black population were excluded from participation in the mainstream political and cultural economy of apartheid South Africa. As a result, the gangster and the outlaw became exalted as the main models of masculinity for African men, over the professional or law-abiding civilian. In brief, Tsotsitaal was mainly associated with forms of 'criminal' resistance to officialdom.

The well-known Soweto uprisings in 1976 against the introduction of Afrikaans as the medium of instruction in education for Black people marked a turning point in the social functions and meanings of Tsotsitaal. The entry of street cultures and the ideologically charged youths of the Black Consciousness movement into the schools led to an overt politicization of Tsotsitaal. Tsotsitaal became the linguistic icon of African youth, allowing for a radical counter-discourse that questioned contrived and received boundaries around social living, class stratification and linguistic observances put in place by the apartheid regime as part of its divide and rule policy in relation to Africans. The anti-Afrikaans sentiment among African youth of the time resulted in the progressive decline of an Afrikaans-based Tsotsitaal and the concomitant emergence of other forms of Tsotsitaal, as it became apparent to its speakers that any African language could become a base language onto which a host of other African languages could be layered. Thus, from the 1980s, there was the emergence of a fascinating variety of linguistic phenomena with various African languages as substrates. This continued to be called Tsotsitaal, or iskasi, or ukuringa or itaal. However, the Zulu-based and Sotho-based varieties remain the most widespread and popular.

By the time South Africa embraced democracy in 1994, Tsotsitaal had third- or fourth-generation speakers, whose understanding of the more standardized forms of indigenous languages could not be fully vouched 
for (Makhudu 1980, 2002; Ntshangase 1993, 2002). Equally, by this time, Tsotsitaal began to appeal to Black female speakers, not only those perceived to be of dubious character, but also those who were highly respected and held in high esteem (see Glaser 1992). In essence, Tsotsitaal has become ubiquitous in Black youth's communicative ecologies as well as in some parent generations. It has become a linguistic variety which, while being true to its historic transgressive moments, underpinned popular Black street-conscious identities (Mhlambi 2010). Vokwana (2007) points out that as in the case of kwaito music, Tsotsitaal, in its articulation, circulation and reception, operates in mutual entanglements with visualities from the Black world, with its collective memory and history. Finally, Hurst (2009) argues that Tsotsitaal has initiated 'a dialogue between its local varieties and the global youth linguistic styles', resulting in 'glocalized' youth identities onto which a host of identity-related symbols have been layered. These symbols have to do with self-stylization trends such as the use of fashion, hairdos, the chewing of a match stick on the side of the mouth, chains and so forth.

In conclusion, Tsotsitaal expressions often coexist with English and other African languages in daily communicative practices in the South African context, giving rise to highly hybridized linguistic combinations. This is not an exception to some kind of ideal alternation of languages, but points to the very messy nature of multilingualism (see Kelly-Holmes and Milani 2011).

Whereas South Africa is often taken as a prime example of multilingualism and multiculturalism, Sweden is described as a country that has been historically homogeneous with regard to the ethno-linguistic composition of its inhabitants. Although it has been extensively demonstrated that this homogeneity is a discursive construction that fails to account for the historical presence of a variety of national minorities on Swedish territory, ${ }^{2}$ such as the Swedish Finns and the Sámi (see Catomeris 2004), the ethno-linguistic composition of the population in Sweden did undergo a major change as a result of considerable immigration during the second half of the 20th century. As statistical data show, the percentage of residents born outside Sweden's borders more than doubled in the last forty years, shifting from 6 per cent in the 1970 s to 13.4 per cent in 2009 (Chapter 14). Admittedly, migrants from neighbouring Finland have maintained their position as the largest

${ }^{2}$ Cognizant of the ideological pitfalls inherent in any labeling attempt (see Chapter 3), we employ the official expression employed by the Swedish state, 'national minorities' (nationella minoriteter) to differentiate groups with a long-standing historical presence on Swedish territory from more recent additions to the Swedish ethnoscape. 
minority group since the 1970s. However, other more distant and unfamiliar ethno-linguistic groups such as the Afghans, the Kurds, the Somalis and the Turks, to name only a few, have recently appeared in the Swedish ethnoscape, and have rapidly increased in numbers during the last ten years. The interesting point embedded in these figures is that the linguistic, ethnic and religious diversity resulting from migration is a visible and tangible reality in contemporary Swedish society. Moreover, considering that migrants settled down mainly in urban environments, the suburbs of the largest cities of Stockholm, Gothenburg and Malmö have become sites of cultural and linguistic contact (Chapters 4 and 5). In order to better understand the Swedish context, it is also relevant to mention a social and architectural project that took place in Sweden in the mid-1960s and 1970s - the so-called Miljonprogrammet (lit. 'Million Programme'). Pressed by the needs of a growing population, the Social Democratic government of the time set out to construct one million dwellings within a period of ten years (1965-74). The goal was to provide good housing conditions at reasonable prices on the outskirts of the main cities. Rising immigration rates, together with particular housing allocation policies and practices, led to an increasingly higher concentration of migrants from very different ethnic groups having to share space as a result of the Million Programme. Unsurprisingly, these urban peripheries have become scripted over time in the public consciousness as icons of 'immigrantness' (invandrarskap) or ethnic Otherness, pitted against ethnically Swedish city centres.

The most tangible linguistic result of these new cultural and ethnic encounters was the emergence of new linguistic phenomena among young people in Swedish urban peripheries. Commonly known as rinkebysvenska ('Rinkeby Swedish'), named for the Stockholm suburb of Rinkeby in which it allegedly originated, or as blattesvenska ('immigrant Swedish') from the derogatory word blatte ('immigrant'), multilingual urban practices among adolescents have become the object of intense academic scrutiny over the last thirty years or so. Ulla-Britt Kotsinas (1992, 2001), who was also the first scholar to employ the label Rinkeby Swedish in academic writing, argues that this linguistic phenomenon is characterized by (among other things): (1) a large number of borrowings from the languages that are spoken in the suburbs, (2) a 'choppy' prosody, (3) the overgeneralized use of some prepositions and verbs, and (4) non-inversion when inverted word order is required ( ${ }^{\star}$ igår jag var sjuk 'yesterday I was sick' instead of igår var jag sjuk 'yesterday was I sick') (Ganuza 2008a: 16; $c f$. Chapter 4, this volume). Because of these non-standard features, it is often difficult to distinguish rinkebysvenska from Swedish interlanguage; that is, the developing output of a second 
language learner (Gass and Selinker 2001), not least because rinkesbysvenska encompasses some interlanguage features (see also Bijvoet and Fraurud 2006). In terms of the social meaning of rinkebysvenska, Kotsinas (1992: 58) points to 'the air of toughness' that pervades this linguistic phenomenon, and goes on to argue:

These Swedish adolescents are apparently trying out immigrant identities in their search for their own social roles and identities. This, in turn, could be seen as an adaptation to the cultural reality in the 'immigrant' areas where they live, a kind of acclimatization to the new Sweden (p. 58).

Rather than 'adaptation' and 'acclimatization', scholars have more recently highlighted the highly subversive aspect of rinkebysvenska, identifying it as something that can only be understood in relation to the broader ideological loading of this linguistic phenomenon in Swedish society (e.g. Milani and Jonsson 2012).

The existing literature on media representations of rinkebysvenska (Jonsson 2007; Jonsson and Milani 2009; Milani 2010; Stroud 2004) testifies to a process of enregisterment (Agha 2007), whereby linguistic practices among urban youth seem to have become icons (Irvine and Gal 2000); that is, essentialized traits of ethnic Otherness, social and educational problems, and more recently of an aggressive sexist and homophobic masculinity. Rinkebysvenska has been generally represented in the Swedish media over the last 30 years or so as a bad and deviant linguistic variety spoken by problematic, chauvinist, non-Swedish young men. And such a negative linguistic image is more or less overtly constructed against the benchmark of standard Swedish as a good, equal and emancipatory linguistic code (see, in particular, Milani 2010).

Of course, considering hegemonic discourses only offers a one-sided picture of the social life of rinkebysvenska, which fails to account for resistant discourses and practices. More recently, Milani and Jonsson (2012) have illustrated the presence of a few more marginal counterdiscourses that have highlighted the linguistic creativity inherent in rinkebysvenska (see Milani and Jonsson 2012). Furthermore, the hegemonic representations of rinkebysvenska widely circulated by the media have been challenged in daily practices.

Haglund's (2005) ethnographic study in a Swedish school illustrates that male and female adolescents are well aware of the higher value of standard Swedish versus multilingualism in Swedish society, an attitude that is also reflected among the teachers of that school. However, these young people do not passively accept this linguistic hierarchy, but contest it in daily interactions. As Haglund (2005: 113) puts it, contestation takes the form of 'objections to the emphasis on monolingualism, 
attempts at claiming the status of multilingualism and varieties of Swedish that are not considered 'pure'. Similarly, Milani and Jonsson's (2012) linguistic ethnography of another Swedish educational context illustrates how speaking standard Swedish is an index of being a good student, whereas rinkebysvenska is synonymous with unruly behaviour in the school under investigation. Pupils (of both genders) indeed subscribe to such a dichotomy. However, the authors show how the usage of standard Swedish is not only found in serious contexts, but may be used mockingly in daily interactions. This leads them to conclude that the adolescents in the study are staging a Bakhtinian carnival that is 'both critical of social order and complicit with it' (Wolfreys 2004: 27).

Overall, metalinguistic discourses in the media seem to promote and circulate an image of rinkebysvenska as an aberrant and deviant offshoot of standard Swedish, and an icon of a similarly anomalous, non-Swedish masculinity. The reality on the ground, however, testifies to a more complex scenario, one in which adolescents of both genders simultaneously reproduce and contest these ideological associations in their daily practices in and out of school.

\section{Tsotsitaal and linguistic hybridity: the reproduction and contestation of cultural stereotypes}

The South African TV commercial we consider is taken from a larger advertising campaign for a new mobile network launched by the partly state-owned telecommunication company Telkom in 2010. The inauguration of this mobile network began with a teaser campaign that did not reveal the brand name and product to be promoted, but drew exclusively upon different representations of the Tsotsitaal word ('Hi') ['hejit ${ }^{\mathrm{h}} \mathrm{a}$ ] in both rural and urban settings. The teaser campaign was soon followed by a full-blown release revealing the introduction of a new mobile network, branded 8.ta. It is not completely new for a telecommunication provider in South Africa to employ African languages as part of its marketing strategy. For example, two of Telkom's main competitors, Vodacom and MTN, had previously capitalized on African languages with a view to attracting new constituencies of Black consumers. What is innovative, however, is that a chat-spelling of a Tsotsitaal word (8.ta for Heita) has been used as the name of the network provider itself. This labelling choice is in tune with a process of self-stylization according to which this network provider aims to present itself as 'a bold, exuberant and forward-thinking brand that ... will win the hearts and minds of South Africans' (www.8ta.com/about-us/). The extent to which such boldness and forward thinking is put to work in the actual advertisements will 
become clearer in the analysis of Extract (1) below (from www.youtube. $\mathrm{com} / \mathrm{watch} ? \mathrm{v}=\mathrm{vRY} 8 \mathrm{sfI}-8 \mathrm{IQ})$.

Scene description: two Black female housekeepers are talking in a spotlessly white kitchen. The first one, slender in physique, is performing her chores while the other, with a stouter figure, is lounging bored by the table.

1 Housekeeper 1 [standing by the counter, washing the dishes]: (sighing) Working hard ne?

2 Housekeeper 2 [sitting by the table, shaking her head bored]: (in a subdued whisper) I am working hard Joe.

3 [suddenly jumping to life as a popular Tsonga ring-tone tune sounds on her mobile phone] Ah, Awuzwe na:zo, ja

4 (Switching to a lower pitched, $\bar{d}$ arker voice and with emphatic tone) re:: volutionary greetings dear ca:lle:r. I'm engulfed by a dee::p serious feelings of joy and merriment.

5 [mirroring herself in the oven door while housekeeper 1 kneels on the counter washing the windows] My eyes feast

6 [now bent over the counter where housekeeper 1 is folding towels] with ...my. . . perpetually. . ula:::te and clean.

7 [standing facing the camera while housekeeper 1 cleans the kitchen fan] Our collision blossoms

8 [arranging a chair whereas housekeeper 1 scrubs the floor on her knees] and skip into my medulla oblongata.

9 [sitting in the same position as when the phone first rang] And I bid you a bi::g farewell.

10 Housekeeper 1: [folding towels] Hawu who was that?

11 Housekeeper 2: Angazi, i-wrong number.

12 Housekeeper 1: Hhee, working hard ne?

13 Housekeeper 2: (Sighing loudly) [Putting back her mobile phone in her bra]

[A prolonged shot of the kitchen portrays housekeeper 2 sitting at the table shaking her head bored while housekeeper 1 stands at the kitchen counter folding a towel. The soundtrack is that of the Tsonga popular tune, which had been the ring tone of the housekeeper's phone. A set of text blocks fly in forming the slogan: EARN FREE MINUTES WHEN PEOPLE CALL YOU]

English is the main language employed in this advertisement. However, several elements from African languages have been interspersed here. To begin with, in turn 1 , the function word ne is derived from a fuller Tsotsitaal form ane, which is used to affirm and solicit an affirmative answer. Etymologically, this form could have emerged from (1) the seSotho word hana which means 'really', or (2) the IsiZulu form $n a$, an emphatic aspect of forming a question. Since one of the main characteristics of Tsotsitaal is to modify words (Ntshangase 1993), it might have replaced the /a/ at the end of the words with an /e/ or 
corrupted /hana/ for /ne/. Alternatively, this function word could be the Afrikaans interjection or confirmatory particle nê (Picard 1988), which corresponds to an English question tag at the end of a sentence.

In turn 2, the name Joe is a shortened form of Joseph/John/Johannes/ Johan. It is a term of endearment, generally used among acquaintances within the same field of work. Originally, the name was employed and gained currency among comrades in the gangster milieu. The usage of the short form Joe has to do with the fact that the full version of the name has biblical associations. Men in the underworld did not want names that constantly reminded them of social morals and family expectations, especially during times of rapid urbanization, when these familial responsibilities and societal obligations proved too much for individuals who decided to break with tradition and cut their links with their rural homes (Glaser 2000).

Also in turn 2, the standard isiZulu expression awuzwe nazo ('hear it, there it is') can only be understood in light of the emergence and development of fast-paced, musical sounds among subaltern working-class individuals, this being the group from which tsotsi subculture emerged. It is important to mention in this context that Black working-class musical culture is highly indebted to traditional forms that encouraged spontaneity, energetic movements, shouts of merriment and jubilation and so on (see Coplan 1985). Awuzwe nazo is precisely one such expression of joy, a response of gusto and enthusiasm to a musical performance. It is no accident that this expression is an exclamation that linguistically marks the housekeeper's enthusiasm in response to a popular Tsonga ring tone.

In turn 11, the expression angazi is an isiZulu or isiXhosa expression meaning 'I do not know', which is followed by $i$-wrong number, an interesting example of linguistic creativity in which the English expression 'wrong number' has been dressed up in an isiZulu grammatical guise. Since, according to isiZulu morphological rules, adjectives in attributive position are required to begin with a vowel, an /i/ has been added to the adjective /wrong/ to form the expression / iwrong number/. As was mentioned earlier, this trend of using English words, mixing them with other African words or couching them in syntactic and morphological structures from African languages, became increasingly common after the demise of Afrikaans-based Tsotsitaal. Finally, in turn 12 , the onomatopoeic Hhe ....hhoo! is an expression that can be rendered as 'of course', especially as a response to a statement of mockery or disbelief.

Overall, the mobilization of these African linguistic resources helps to firmly anchor the conversation in the South African context, where the mixing and fusing of linguistic material is a key component of daily 
interactions among Black speakers (see Blommaert 2005). At the same time, the cultural connotations borne by these linguistic expressions also help to conjure up an image of insolent Black womanhood, defying established norms for what is considered an acceptable domestic work ethic. Most importantly, the 'keying' (Hymes 1974; see also Coupland 2007) of the whole advertisement is humorous; it is 'intended to amuse' (Tannen 2005: 164). In this context, humour is generated both at the level of register and content of the advertisement, as the result of a series of incongruities and disjunctions between opposing registers, voices and practices (see Bakhtin 1981, 1986; Billig 2005: 127).

There is a juxtaposition between what are considered to be expected and unexpected registers of speech for a Black South African housekeeper: (1) the highly colloquial and hybrid language of the exchange between the two housekeepers (which is expected), and (2) the high register of English employed in the phone monologue in which the first housekeeper is engrossed for most of the advertisement (which is not expected). The second, and perhaps most patently comic element lies in the obvious discrepancy between housekeeper 2's claim to be working hard, and the fact that she is actually leaving all the chores to her co-worker.

Read through a postcolonial lens, the advertisement undoubtedly draws on a well-known stereotype in the South African context, that of the sluggish and rude Black maid who does nothing but complain about the amount of work she has to do. It may be possible to suggest that the advertisement capitalizes on and reproduces colonial representations of Black people as inherently lazy. Such an interpretation is in our view too simplistic, not least because it fails to do justice to the multilayered complexity of this advertisement. As we will illustrate in the remainder of this section, there are two subtle elements of resistance, which can only be grasped against the backdrop of discourses and practices of domestic work in the South African context.

Domestic service has come under sharp criticism, and Black women have devised many ways to subvert the problems associated with this form of employment. First, considering that the wages of these workers are normally a pittance, housekeepers have devised ways of working as little as possible, such as perpetual go-slow actions, so as not to overexert themselves unduly. Moreover, if there are two or more doing the same job, the duties are shifted to the one who is most afraid of authority. Seeking to keep work at a minimum and depending on a co-worker's efforts are precisely what the advertisement portrays.

The second way through which housekeepers lighten the burden of domestic service is through the creation of illusions, this being a 
process that often involves stylizations (Bakhtin 1981, 1986; Coupland 2007) of the identities and behaviours of their superiors (i.e. employers, politicians, etc.). From a diachronic perspective, such a form of imitation is not new, but is part of a longer historical legacy that began with the African intelligentsia in the 19th and 20th centuries embodying, reproducing and parodying the Victorian demeanour of the missionary fathers (Comaroff and Comaroff 1991). Linguistically, Bakhtin has taught us that stylization manifests itself in the fact that 'our speech ... is filled with others' words ... These words of others carry with them their own expression, their own evaluative tone, which we assimilate, rework, and re-accentuate' (1986: 89). To this, one could add Goffmann's observation that accent shifts are important linguistic cues for stylizations in that they index changes of frame, which in turn involve the activation of certain identities while others are made latent (Coupland 2007: 112ff).

In the light of this theoretical backdrop, the accent shift made by housekeeper 2 when answering the phone constitutes an important linguistic element that flags the beginning of a complex stylized performance. Not only does the accent shift mark a change of frame here from the seemingly prosaic face-to-face interaction between the two housekeepers to a more exciting phone-mediated conversation; it also signals a subtler shift from the world of hard everyday reality to the dream world of aspiration (see Nuttall 2004). This interpretation can be justified given the indexical values of English versus hybrid linguistic codes in post-apartheid South Africa, a context in which English has gained status as the language of aspiration to a better, idealized and perhaps never achievable future, whereas African languages are generally seen as less worthy because they are associated with the everyday reality of deprivation (see also Stroud and Mpendukana 2010).

A different interpretation emerges however if one considers the speed of delivery in the high register English sequence versus the linguistically hybrid sections. The fact that the English parts are delivered at a slower speed is not only a strategy through which the housekeeper can prolong the conversation and thus earn more free minutes; a slower pace could also be interpreted as an implicit metapragmatic device through which to convey a negative comment on the artificialness of English and the world associated with it. Conversely, the fast pace of the linguistically hybrid sections highlight non-standard linguistic resources as the authentic language of daily life.

Regardless, the housekeeper is manipulating a variety of linguistic resources that allow her to present an ambiguously multifaceted persona. On the one hand, her parroting of a series of disconnected, meaningless but nonetheless emphatic sentences of high-brow language so common 
among many South African politicians contributes to making her a Black version of Mrs Malaprop, the well-known and pretentiously ignorant character in Sheridan's play, The Rivals. On the other hand, if one considers her rather skillful rendition of the high register of the utterances, it could be argued that the housekeeper is actually a well-accomplished actor aptly presenting a sophisticated and linguistically competent persona. Whether ignorant or sophisticated, what is most important for the purpose of the advertisement is that she appears as an economically streetwise woman, someone who proves she is able to exploit the situation to her advantage, and ultimately succeeds in earning free minutes by managing to keep her caller on the phone. Such ambiguity is also noticeable at the level of humour; one ends up laughing at the housekeeper while surreptitiously giggling with her at the anonymous caller's unwitting complicity in contributing to her phone credit.

\section{Swedish interlanguage and rinkebysvenska: the discursive construction of the exotic Other}

The first Swedish advertisement we analyse is a TV commercial for the Swedish state lottery, Lotto (see www.youtube.com/watch?v=hJoz11$\mathrm{Ju} 7 \mathrm{xw}$ ). Extract (2) portrays a blond woman lying on a beach chair next to a glassy blue swimming pool in what looks like a warm holiday paradise. Suddenly, a genie wearing a fez and a caftan appears out of a cloud of smoke on the chair nearby. This character is played by a man in his 50 s or 60 s with relatively dark features, which in Sweden would usually evoke associations with people from the Middle East. Happily surprised, the woman lowers her sunglasses, turns to the genie and begins a conversation with him.

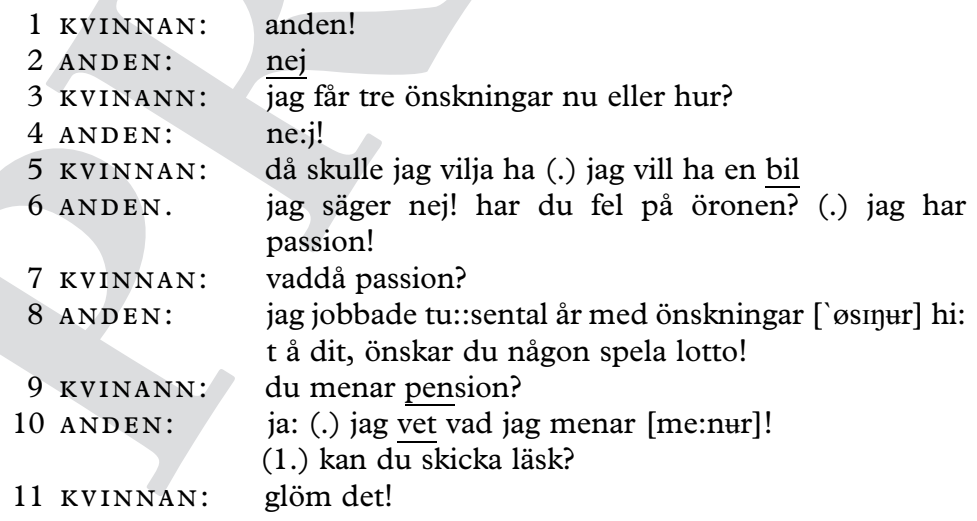




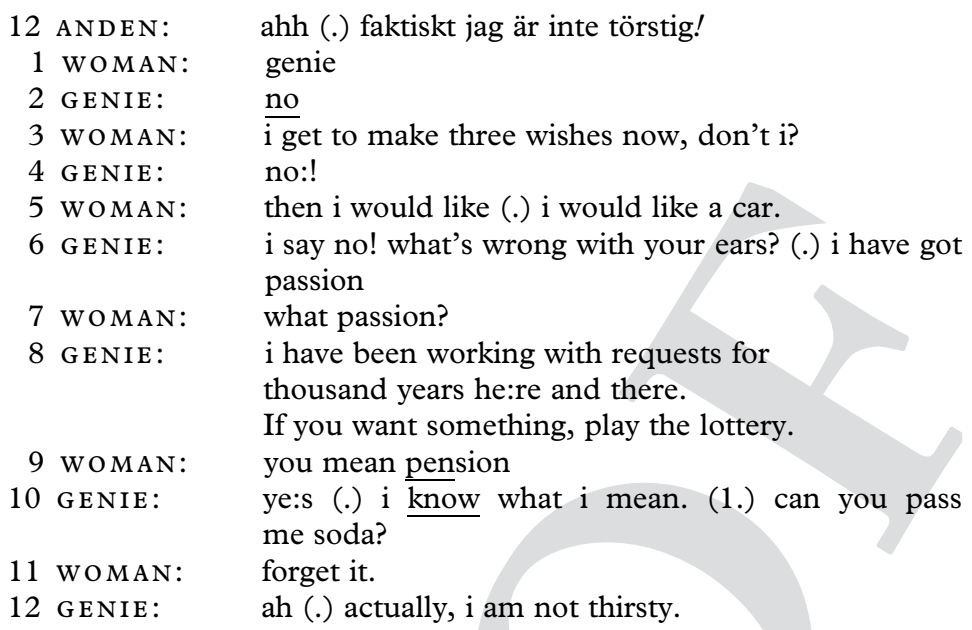

Linguistically, the utterances produced by the genie encompass a variety of non-standard phonetic, syntactic and lexical features: (1) the dropping of the consonant [s] in tusental (instead of tusentals), (2) the pronunciation of [me:nur] instead of [me:nar], and [øsinur] instead of [ønskningar], (3) the non-idiomatic usage of the expression har $d u$ fel på öronen ('what's wrong with your ears') instead of har $d u$ fel på hörseln ('what's wrong with your hearing'), (4) the malapropism passion instead of pension and (5) non-inversion when inverted word order is required after the adverb faktiskt ('actually') in initial position (faktiskt jag är inte törstig $>$ faktiskt är jag inte törstig). Taken together, all these linguistic features that deviate from standard Swedish could be seen as tokens of interlanguage, and thus contribute to evoking the image of the genie as a second-language learner of Swedish (see also the introduction above).

Quite unoriginally, the advertisement draws on and reproduces a well-established trope in Swedish media discourse according to which non-nativeness is treated as inextricably entwined with ethnic Otherness (see Milani 2008, 2010; see also Androutsopoulos $2010 b$ for a similar example in the German context). Put simply, the argument runs as follows: if you are a non-Swede, you cannot be a native speaker of Swedish, and vice versa. As Jonsson (2007) and Milani (2010) point out with regard to public debates on rinkebysvenska, the link between (non-standard) language and ethnicity (= non-Swedishness) also encompasses gender (= masculinity) and age (= youth) components in such a way that rinkebysvenska has become the icon of young and multiethnic/immigrant masculinity. 
The intersection between language, gender, ethnicity and age is also present in the TV-commercial in Extract (1). However, the difference lies in the age aspect of the ethnic Other. Unlike rinkebysvenska, which is deeply bound up with adolescence, interlanguage both informs and is informed by middle-agedness. The genie is, in our view, another embodiment of the immigrant man (see also Tigervall 2005), a character who, despite having been in Sweden for a long time, never really succeeded in acquiring Swedish properly, nor did he manage to develop the necessary symbolic competence (Kramsch 2006) in Swedish sociocultural rules, whatever this may be.

Needless to say, 'ways of talking about the 'Other' are ways of talking about ourselves' (Woolard 1989: 276), which is apparent in the juxtaposition between the Middle Eastern, non-Swedish, non-native male speaker and the Western, Swedish, female native speaker. Interestingly, the TV-commercial exploits a particular orientalist view of the Self/Other divide. As Said (1978) has argued, orientalism can be defined as 'a political vision of reality whose structure promoted the difference between the familiar (Europe, the West, 'us') and the strange (the Orient, the East, 'them')' (Said 1978: 43). What is key in this context is how the non-native speaker has been semiotically exoticized through the wellknown cultural reference to the tale of Aladdin in Thousand and One Nights, which, together with the attire (the fez and the kaftan), highlights and authenticates (see Bucholtz 2004) such cultural association.

These orientalizing practices with regard to non-nativeness are neither new nor unusual; they have been singled out elsewhere in an analysis of representations of Rinkeby Swedish in the media (Stroud 2004). As Stroud suggests with regard to a textual extract in his data set, the representation of women in long dresses carrying heavy loads of food together with the concomitant portrayal of a men gathering outside the local mosque has the rhetorical effect of 'driving home the exotic Otherness of a superficially mundane everyday scene in the suburbs of Stockholm' (Stroud 2004: 201). What is perhaps more novel in the advertisement under investigation here is the humorous treatment of the exotic Other. The comic element lies in the disjunction between the expected and actual behaviour of the genie. Whereas, according to a well-known literary script, he is supposed to grant three wishes, his stance in the advertisement is that of denial, as testified by the brusque refusal ('no') to the woman's question, which is repeated after the woman goes on to make her request regardless.

In this regard, Cameron (2007) has noted that refusals are dispreferred choices in conversation because they can easily be perceived as rude and confrontational. Rudeness is enhanced further in the advertisement by a sequence of bald-on-record strategies (Brown and Levinson 1989) 
in the genie's speech (see in particular the unmitigated statements of fact and the orders expressed through imperatives). The presence of these linguistic features should not, however, lead us to conclude that the genie inhabits a more powerful position vis-à-vis a powerless woman (see Kiesling 1997 for an important contribution to the study of language, power and masculinity). Rather, it would be more appropriate to characterize the entire verbal exchange as a surreal power struggle, one which actually ends with the linguistic triumph of the woman, insofar as she draws on her privileged linguistic knowledge as a native speaker in order to ridicule the genie's linguistic incompetence (see also Davies 1990), which, in turn, contributes to questioning his authority, and ultimately makes him look like a fool. As was the case for the 8.ta advertisement analysed in Extract (1), however, it would be an oversimplification to argue that the viewer unconditionally laughs at the genie. Nothwithstanding the woman's linguistic victory, her stiff and stubborn behaviour, together with the complete lack of sense of humour, makes her the target of the viewer's teasing gaze as well.

That the ethnic Other is exploited in mainstream Swedish advertising can be further substantiated by looking at Extract (3) from the TV commercial for the Swedish technology chain Elgiganten (see www.youtube.com/ watch? $\mathrm{v}=\mathrm{fg} 2 \mathrm{gLapBFow}$ ), which features one of the most famous public figures with whom rinkebysvenska is associated, the well-known Swedish hip-hop artist of South American descent, Dogge Doggelito.

The advertisement opens with a silhouette of a person walking a bicycle through the door of a dark and seemingly underground parking lot. Moving towards the camera, the silhouette fades in revealing a smiling Dogge Doggelito wearing a tight blue, white and black lycra cycling outfit and a helmet. In the shot that follows, we are shown the people at whom Doggelito was smiling, namely three individuals - a woman and two men hanging around next to an exclusive sports car. It is at this juncture that Doggelito starts using the staccato prosody which has been singled out as the most typical feature of rinkebysvenska (cf. Bodén 2010; Chapter 7, this volume), embedding it into the cadence of a rap song.

$$
\begin{aligned}
& 1 \text { kolla in stilen } \\
& 2 \text { cykel på köpet } \\
& 3 \text { gjorde värsta dealen } \\
& 4 \text { cykel på köpet } \\
& 5 \text { spara feta slanten } \\
& 6 \text { cykel på köpet } \\
& 7 \text { kom till Elgiganten } \\
& 8 \text { cykel på köpet }
\end{aligned}
$$

1 check the style

2 get a bike for free

3 did the worst deal

4 get a bike for free

5 save fat bucks

6 get a bike for free

7 come to Elgiganten

8 get a bike for free 
The rapping scene is followed by a shot of the three people in the garage all wearing cycle helmets, bobbing their heads to the rhythm of the song. The advertisement ends with the appearance of a laptop next to Doggelito, who says in the same staccato rhythm that characterizes his rapping: Toshiba laptop, det du, det är drömmen det! . . Och cykeln på köpet! ('Toshiba laptop, hey, it's a dream! And get a free bike!').

Just as in the commercial for the Swedish lottery, the non-native speaker of Swedish is orientalized as an amusing exotic character, in opposition to the more familiar, normal, but nonetheless humourless native speaker. The speaker of rinkebysvenska appears here as comically strange. The comic effect is the result of a series of incongruities, especially when compared with the other male characters in the advertisement.

First, Doggelito's cycling outfit does not match the clothing style one would expect from a rapper. Note, however, the presence of the thick metal necklace, which is itself out of place in the context of the cycling outfit. Second, Doggelito's forced smile contrasts with the seriousness of the other characters. Third, the rather mundane issue of receiving a free bicycle is rather at odds with the criminal, underground atmosphere of the setting and the other male characters. Their shadiness is conveyed through a set of characteristics: (1) both men wear sunglasses, despite the fact that they are inside a garage; (2) they have very short hair; (3) one of them sports a goatee, whereas the other is unshaven; and (4) both of them wear thick metal necklaces. Taken together, all these elements help to conjure up an image of a tough and devious, but nonetheless out-of-place masculinity, which is at variance with the rather unthreatening and no less unfitting demeanour of Doggelito's character.

Having said that, Doggelito's mastery of the hip-hop technique makes him appear so authentic that he can still be himself in an outfit that is not hip hop at all. Moreover, the reliance on a genre in which 'keeping it real' is so central allows Doggelito to present a strong and self-confident persona, who can offer a lesson of consumerist astuteness to more or less (un)threatening mafia-like individuals.

In conclusion, both TV commercials are built on problematic stereotypical cultural models of who counts as the ethnic Other in Sweden, represented by a character who is odd in many respects, and therefore comic. Indeed, the mobilization of the immigrant man under the guise of the exotic genie reproduces a well-established conflation between non-nativeness and non-Swedishness. However, the Swedish Self is no less exempt from mockery in these advertisements. Such humorous instability also emerges as the result of the re-semiotization (Iedema 2003) of Swedish hip-hop singers and rinkebysvenska in the 
advertisement genre. Here, the subversive potential of these semiotic resources has been tamed in the interests of consumerist logic, and their speaker/performer has been re-signified from the intimidating, dangerous, sexist young man, into an unthreatening and comic but nonetheless real and smart character, someone not only to laugh at but also to listen to in order to get a good deal.

\section{Discussion and conclusion}

In answering the question of where examples of postcoloniality can be found, Loomba (1995: 14) warns against facile comparisons between or even conflations of "minority' people living in the West' and 'the peoples living in 'third world' countries', for although they 'may share cultural roots, and may also share an opposition to the legacy of colonial domination, their histories and present concerns cannot simply be merged'. With this caveat in mind, we strongly believe that there is a value in applying a postcolonial lens to contexts that are not usually associated with colonialism, as is the case of Sweden (de los Reyes, Molina and Mulinari 2006), because it allows us to show how processes of exoticizing and othering are not the prerogative of backward and developing contexts, but are at work even in what are believed to be most liberal and progressive democracies. Moreover, the choice of Extract (1), a media example from South Africa was not random, nor was the comparison with Swedish advertisements, Extracts (2) and (3). In making these choices, we were motivated by Comaroff and Comaroff's suggestion that the Global South is a 'harbinger of future-history' (2012: 12). In the specific case of the linguistic phenomena at the heart of this chapter, there is little doubt that Tsotsitaal has become an index of political emancipation after Soweto. Because of this, it is no longer simply seen as the language of deviant male youth. Rinkebysvenska, on the other hand, does not seem to have gone through a similar process of re-evaluation (at least not to the same extent). This emerges clearly in the commercials. The Swedish advertisements rely heavily on a stereotypical linkage between non-normative linguistic practices and non-Swedish masculinity, thus implicitly erasing the role of female speakers in these linguistic phenomena. In contrast, the 8:ta commercial is set in a realistic everyday environment (a kitchen in a wealthy home), and seems to capitalize on the fact that Tsotsitaal is not the precinct of men, but can also be strategically employed by women as well. In sum, Tsotsitaal is what rinkebysvenska might become in a few years or so.

These differences notwithstanding, the advertisements have several traits in common. These allow us to go back to the main theoretical 
argument with which we started this chapter, namely that North-South and centre-periphery oppositions are not always productive. Without naively downplaying historical differences and economic imbalances of different contexts, it is these similarities that will enable us to better understand global sensitivities that cut across geo-political and economic divides in late modern conditions.

To begin with, non-normative urban linguistic practices traditionally associated with youth have been employed for consumerist purposes. Interestingly, however, such vernaculars have been voiced by less young speakers in the advertisements in question, thus questioning the applicability of the very notion of 'youth language' to rinkebysvenska and Tsotsitaal. That a mobile network provider chooses a Tsotsitaal form of salutation as its branding label might not lead per se to state recognition of Tsotsitaal. Likewise, the usage of rinkebysvenska and non-standard pronunciation might not lead per se to enhanced public acceptance of non-normative linguistic practices. However, the choice of these urban non-standard vernaculars (instead of other linguistic resources) could be taken as the manifestation of an 'anti-standardizing move' (Gal 2006: 27), which might have ideological implications in the near future. This is insofar as linguistic phenomena which have traditionally been associated with less worthy, backward or threatening practices and traditions are being deployed in these advertisements as indices of contemporary consumption (see Gal 2006: 27).

Taking a somewhat more pessimistic stance, one should however not forget that in these TV commercials, the speakers of urban vernaculars (Chapter 2) embody essentialized and overall negatively laden cultural stereotypes. From this perspective then, these advertisements could be seen as controversial acts that boldly flout the discursive conditions of Sweden and South Africa, two contexts where overtly negative representations of the ethnic and racial Other are frowned upon. The only means through which this may be accomplished is humour, a well-established rhetorical manoeuvre through which to create semiotic instability. Humour not only makes it difficult to counter the negative racial and ethnic connotations in these TV commercials, but also helps to mitigate the responsibility of the producers vis-à-vis the content of their media output (see Benwell 2004: 163 for a similar point about irony in speech).

Needless to say, the meaning of humour is notoriously difficult to pin down. Following Billig (2005), it can be divided into two broad categories: disciplinary humour and rebellious humour. As he goes on to explain: 
Disciplinary humour mocks those who break social rules, and thus can be seen to aid the maintenance of those rules. Rebellious humour mocks the social rules, and, in its turn, can be seen to challenge, or revel against, the rules (p. 202).

As Billig (2005) himself acknowledges, such a distinction is however difficult to operationalize in practice because, as Bakhtin (1984: 127) has taught us, humour operates like a carnival mirror of the world. It is a conformist and insubordinate rhetorical weapon, which simultaneously reproduces and contests dominant beliefs and stereotypes (see also Blackledge and Creese 2010).

Overall, the main characteristic shared by the advertisements in this chapter is that they do not just reproduce and circulate well-known stereotypes, but also re-signify and, to a certain extent, unsettle them. The lazy Black housekeeper is re-cast as a streetwise economical person, and the threatening non-Swedish rapper re-framed as a docile, albeit strange advisor on a good deal.

The economic imperatives underpinning this ambiguity should, however, not be underestimated. Echoing Foucault's (1991) observations that individuals' freedom of choice in contemporary society is nothing but a chimera in the service of modern power, Billig explains that

humour directly aids the economic structures that have produced such enjoyment. The more we laugh and the more we imagine ourselves to be daringly free in the moments of our laughter, the more we are complying with the demands of the so-called free market (2005: 212).

In sum, utilizing subversive linguistic practices and incorporating them into mainstream media manifests a particular consumerist sensitivity, which recognizes the importance - necessity even - of including ethnic and racial diversity in marketing outputs. From a purely textual analysis, it is not always clear whether this choice is a form of symbolic recognition of such diversity or a strategic move to attract increasingly larger constituencies into consumption. Either way, the ambiguity in their humorous character seems in our view to be bound up with the main incongruity of capitalist economy. For capitalism to reproduce itself and flourish, consumption needs to be constantly increased through (among other things) the promise of individual betterment, but this can only be attained by leaving socioeconomic structures and (im)balances intact. Likewise, whether rebellious or disciplinary, the laughter at or with ethnic and racial stereotypes might enact a fleeting moment of 'freedom from the restraints of social convention' (Billig 2005: 208) or an ephemeral relief from the discomfort of daily life. Ultimately, however, such humour can only work provided it leaves unchallenged the very ethnic and racial categories it mocks. 


\section{TRANSCRIPTION CONVENTIONS}

(.)

[standing by the counter] (sighing)

:

$::$

Swedish

\section{?}

$!$ a short pause of less than one second a longer pause, time in seconds stage directions paralinguistic features lengthened sound more lengthened sound underlined, said with stress marks question intonation marks exclamation intonation 